\title{
УДК: 612.766.1+616-084:001.5
}

\section{HAПPУХKEHICTЬ ПPAU GIK ФAKTOP ПРОФЕСІЙНОГО СТРЕСУ ТА РИЗИКУ ЗАОРОВ'Ю}

\author{
Кундієв Ю.І.1, Чернюк В.І.', Шевиова В.М.2 \\ 1 Інститут меАицини праші АМН України, м.Київ \\ 2 Український $\mathrm{H} \Delta \mathrm{I}$ промислової меАишини, м.Кривий Ріг
}

Розглянуто роль високого нервово-емоційного напруження як фактора ризику порушень здоров'я. Запропоновано нові підходи до кількісної оцінки напруженості праці на основі критеріїв «Гігієнічної класифікації праці за показниками шкідливості та небезпечності факторів виробничого середовища, важкості та напруженості трудового процесу». Проаналізовано сучасні дані літератури щодо впливу напруженої роботи на стан здоров'я та визначено основні нозологічні форми виробничо-зумовленої патології, яка може бути спричинена впливом цього шкідливого виробничого чинника. 3 урахуванням світового досвіду вивчення професійних ризиків здоров’ю та сучасних методичних підходів рекомендовано схему організації та проведення досліджень для виявлення та оцінки ризиків, пов'язаних з впливом напруженої праці.

Ключові слова: напруженість праці, професійний етрес, здоров'я, професійний ризик, методика визначення

Новою ідеологією профілактичної медицини, що базується на прогнозуванні та попередженні несприятливого впливу на організм людини шкідливих чинників оточуючого та виробничого середовища, $€$ дослідження та оцінка ризиків здоров'ю, зокрема професійних ризиків. Вони, зазвичай, пов'язані 3 впливом шкідливих виробничих чинників різної природи, з яких добре відомі фізичні, хімічні, біологічні. Дещо менш поширеними, але не менш небезпечними для здоров'я, є психофізіологічні чинники. За ГОСТ 12.0.003-74 ССБТ «Опасные и вредные производственные факторы. Классификация» вони поділяються на фізичні та нервово-психічні перевантаження. Останні е притаманними трудовій діяльності в умовах застосування новітніх технологій, характерними рисами яких стали високий інформаційний пресинг та дефіцит часу у людини-оператора. Результатом є високе нервово-емоційне напруження, що зазвичай супроводжує трудову діяльність у професіях розумової праці. Тим самим науково-технічний прогрес, орієнтований на використання суперскладних інформаційних технологій, часто без урахування медико-біологічних та фізичних можливостей людини, став джерелом професійного психоемоційного стресу. Про стрес часто говорять як про захисну реакцію організму, попередника порушень здоров'я. Проте необхідно зазначити, що певний рівень робочого стресу, тобто напруження функціональних систем організму, $є$ необхідною умовою виконання виробничого завдання і завжди присутній у трудовій діяльності [15, $18,21]$. Так, при розумовій діяльності мають місце функціональні зміни показників уваги, пам'яті, ве- гетативних регуляцій, показників діяльності серцево-судинної системи, що зазвичай швидко відновлюються під час відпочинку.

Хронічна втома (перевтомлення) принципово відрізняеться від описаного вище стану тим, що має системний незворотній характер і здатна «накопичуватися» в організмі [20]. Існує думка, що хронічний психоемоційний стрес як передпатологічний стан розвивається у людини в результаті не тільки тривалого робочого напруження, але й тривалих негативних емоцій $[11,12,22]$. Результатом його систематичного впливу є порушення адаптаційних механізмів діяльності нервової, ендокринної, імунної, гормональної та інших систем організму, формування дистресових станів, що створюе загрозу здоров'ю людини $[1,19-22]$. Саме цим обумовлюеться професійний ризик здоров'ю, пов'язаний 3 впливом високої напруженості праці.

Дослідження професійних ризиків здоров'ю зазвичай базується на кількісному визначенні рівнів (дози, експозиціï) впливу того чи іншого чинника та кількісній оцінці біологічних ефектів такого впливу. Тобто в класичному випадку йдеться про пошуки закономірностей «рівень-час-ефект» та іх кількісну оцінку. Це принципове положення потребує від дослідника чіткої уяви про те, чи можлива кількісна оцінка рівнів фактора ризику, а також чи можлива кількісна характеристика його біологічної дії.

Так само, вирішуючи завдання дослідження професійних ризиків, пов'язаних з напруженістю праці, зокрема впливу цього чинника на функціональний стан, розвиток втоми чи порушень здоро- 
в'я працюючих, слід насамперед визначитися у наступному:

- яким чином здійснювати кількісну оцінку напруженості праці?

- що вважати проявом шкідливої біологічної дії цього виробничого чинника, і яким чином кількісно оцінити його вплив?

За сучасними уявленнями, «напруженість праці» - це узагальнене поняття, що інтегрує різні шляхи та механізми впливів чинників, що формують нервово-емоційне навантаження у працюючої людини. Ці чинники можуть мати якісну та кількісну характеристику та бути згруповані відповідно до характеру навантажень: інтелектуальні, сенсорні, емоційні, чинники, що пов'язано 3 активністю людини в трудовому процесі та режимом праці.

Кількісну оцінку цих окремих видів навантажень та іх комплексну оцінку здійснюють за критеріями «Гігієнічної класифікації праці за показниками шкідливості та небезпечності факторів виробничого середовища, важкості і напруженості трудового процесу» (ГН 3.3.5-3.3.8;6.6.1-083-2001).

Слід зазначити, що «Гігієнічна класифікація праці...» - единий документ санітарного законодавства, що дає можливість кількісної оцінки напруженості праці за класом умов праці і, тим самим, забезпечує формальну можливість пошуку закономірностей біологічних реакцій (у тому числі порушень здоров'я) залежно від рівнів напруженості праці.

Дотримуючись правил та послідовності дій щодо визначення показників напруженості трудового процесу згідно з критеріями «Гігієнічної класифікації праці.....», можна отримати кількісну оцінку цього показника за класом умов праці - від 1 (оптимальні умови) до 3.3 (високий ступінь шкідливості).

Проте, на жаль, слід визнати, що такий формальний підхід містить низку недоліків. Зокрема, це стосуеться однакового оцінювання наявності від 1 до 5 показників, що перевищують допустиме значення в межах одного класу (клас 3.1 або 3.2 ), і лише наявність 6 і більше таких показників дає підстави для оцінки напруженості праці на 1 ступінь вище. Ускладнюеться розуміння доречності такого підходу за наявності одночасно кількох показників класу 3.1 та класу 3.2. Так само як неможливість оцінювання напруженості праці за класом 3.4 ., хоча за визначенням цього класу, наведеним в «Гігієнічній класифікації праці ...», така можливість мусить бути передбачена.

Отже, потреба в удосконаленні методів кількісної оцінки напруженості праці очевидна. I, в роз- виток методичних підходів, започаткованих в «Гігієнічній класифікації праці... », з'явилися подальші розробки в цьому напрямі $[8,9,17,25,26]$. Зокрема В.В.Матюхин [17] пропонуе застосування інтегрального показника напруженості праці $\left(\mathrm{L}_{\mathrm{Hn}}\right)$ в умовних одиницях як суму значень 5 -и комплексних показників по кожному з 5 -ти блоків нервових навантажень, що враховуються «Гігієнічною класифікацією праці...». Комплексні показники кожного 3 п'яти видів (блоків) нервового навантаження - інтелектуального $\left(\mathrm{L}_{1}\right)$, сенсорного $\left(\mathrm{L}_{\mathrm{II}}\right)$, емоційного $\left(\mathrm{L}_{\mathrm{III}}\right)$, пов'язаного з монотонією праці $\left(\mathrm{L}_{\mathrm{IV}}\right)$ та режимом праці $\left(\mathrm{L}_{\mathrm{V}}\right)$ - обраховуються 3 поправкою на величини деяких вагових коефіцієнтів, отриманих автором на основі математичного аналізу досить значного матеріалу власних досліджень. За В.В.Матюхиным [17] інтегральний показник напруженості праці обчислюють за формулою:

$$
\mathrm{L}_{\mathrm{HI}}=\mathrm{L}_{\mathrm{I}}+\mathrm{L}_{\mathrm{II}}+\mathrm{L}_{\mathrm{III}}+\mathrm{L}_{\mathrm{IV}}+\mathrm{L}_{\mathrm{V}} \text { (ум. од.), }
$$

де $\mathrm{L}_{\mathrm{l}} \cdots \mathrm{V}$ - комплексні показники напруженості праці за окремими блоками навантажень, що обраховуються за формулою (на прикладі блоку $\mathrm{L}_{1}$ - iнтелектуальні навантаження):

$$
\mathrm{L}_{1}=\frac{(\Sigma \mathrm{B})}{\mathrm{N}} \cdot \mathrm{K}_{1},
$$

де $\Sigma_{Б}-$ сума балів показників інтелектуального блоку; $\mathrm{N}$ - кількість показників інтелектуального блоку; $\mathrm{K}_{\mathrm{I}}$ - ваговий коефіцієнт, значення якого дорівнює 0,08 .

Величини вагових коефіцієнтів для окремих блоків прийнято такі:

$\mathrm{K}_{\mathrm{l}}=0,08 ; \mathrm{K}_{\mathrm{II}}=0,16 ; \mathrm{K}_{\mathrm{III}}=0,21 ; \mathrm{K}_{\mathrm{IV}}=0,16 ; \mathrm{K}_{\mathrm{V}}=0,10$.

Проте в концепції автора існує досить спірне уявлення про роль кожного окремого блоку як фактора формування рівня нервово-емоційного напруження. Так, не зовсім зрозумілим є надання переваги емоційним навантаженням як фактору, через який найбільшим чином реалізуеться напруженість праці (коефіцієнт 0,21 ), перед сенсорними, а особливо, інтелектуальними навантаженнями, роль яких, на думку автора, $є$ найменшою (коефіціент 0,08 ) у формуванні інтегрального показника рівня напруженості праці. Разом $з$ тим, для дослідження професійних ризиків можна запропонувати більш простий підхід у кількісній оцінці напруженості праці з урахуванням усіх 22 окремих показників, що містить «Гігіенічна класифікація праці...». Для цього кожному класу умов праці надається бальна оцінка за такою шкалою: 1 кл. - 
1 бал; 2 кл. -2 бали; 3.1 кл. -3 бали; 3.2 кл. -6 балів; 3.3 кл. -9 балів; 3.4 кл. - 12 балів. Після визначення інтенсивності кожного 322 показників за класом умов праці підсумовують їню кількість у кожному класі, і сума перемножуеться на кількість балів, присвоених цьому класу. Далі загальну суму балів ділять на кількість показників, що досліджувалися (22), і отримують середню оцінку напруженості праці в балах:

$$
\mathrm{H}_{\mathrm{n}}=\frac{\Sigma \text { балів }}{22} \text { балів }
$$

У таблиці 1 наведено порівняльні дані інтегральної кількісної оцінки напруженості праці за різними методиками для поширених професій розумової праці.

Порівняльні дані, що наведено в таблиці 1, свідчать, що застосування запропонованих підходів до кількісної оцінки напруженості праці при визначенні професійних ризиків здоров'ю є більш доречним порівняно 3 формальною оцінкою за «Гігіенічною класифікацією праці...». Як бачимо, одному й тому самому класу умов праці можуть відповідати різні рівні напруженості праці за бальною оцінкою чи за оцінкою в умовних одиницях. А це свідчить про більшу привабливість таких оцінок для подальшого застосування в математичних розрахунках ризиків, ос- кільки більш диференційована оцінка фактора ризику надає більше можливостей для визначення наявності впливу цього чинника на стан здоров'я, працездатність та інші показники в експонованих осіб. Як бачимо, можна застосовувати як спосіб бальних оцінок, так і визначення напруженості за умовними одиницями. Проте спосіб бальних оцінок, на наш погляд, є простішим для застосування, хоча і потребує подальшої перевірки та вдосконалення.

За наявності розширених можливостей кількісної оцінки напруженості праці повстає питання щодо вибору адекватного показника впливу цього чинника на працюючу людину. Проте, коли йдеться про оцінку професійного ризику здоров'ю, перевагу слід надавати дослідженням саме стану здоров'я працівника. Слід зазначити, що останніми роками увага до впливу підвищених психоемоційних навантажень на стан здоров'я людини значно зросла. Це пов'язано з виявленням таких феноменів як синдром Кароші - миттева смерть на робочому місці та «burnout diseases» - «випалювання» або «вигоряння». Близьким до цих станів є «синдром хронічної втоми» (CXB), описаний вченими Фінського інституту здоров'я [27, 28, 32].

$€$ свідчення, що на синдром «burnout diseases» в країнах Європи, Америки, Японії страждають до $60 \%$ працюючих в умовах інформаційного та нер-

Інтегральні показники напруженості праці для різних професій

\begin{tabular}{|l|c|c|c|}
\hline \multicolumn{1}{|c|}{ Професія } & $\begin{array}{c}\text { Клас напруженості } \\
\text { прапі * }\end{array}$ & $\begin{array}{c}\text { Показники напруженості (Пн) } \\
\text { за бальною опінкою }\end{array}$ & $\begin{array}{c}\text { Показники напруженості } \\
\text { (Lm) в ум. од. ** }\end{array}$ \\
\hline $\begin{array}{l}\text { Майстер на машинобудівному } \\
\text { заводі }\end{array}$ & 3,2 & 1,95 & 1,23 \\
\hline $\begin{array}{l}\text { Телефоніст міжнародного } \\
\text { зв'язку }\end{array}$ & 3,2 & 2,54 & - \\
\hline $\begin{array}{l}\text { Диспетчер стартового } \\
\text { диспетчерського пункту }\end{array}$ & 3,2 & 2,54 & 1,931 \\
\hline $\begin{array}{l}\text { Авіадиспетчер т/п управління } \\
\text { повітряним рухом }\end{array}$ & 3,3 & 3,18 & 1,775 \\
\hline $\begin{array}{l}\text { Диспетчер аеродромного } \\
\text { диспетчерського пункту }\end{array}$ & 3,2 & 1,78 & - \\
\hline $\begin{array}{l}\text { Диспетчер регіонального центру } \\
\text { (а/п Бориспіль) }\end{array}$ & 3,3 & 2,86 & - \\
\hline $\begin{array}{l}\text { Диспетчер стартового диспет- } \\
\text { черського пункту (а/п Жуляни) }\end{array}$ & 3,2 & 2,5 & 2,312 \\
\hline Пілот збройних сил & 3,3 & 4,1 & 1,14 \\
\hline Науковець & 2 & - & 1,051 \\
\hline Конструктор & 2 & - & 1,291 \\
\hline $\begin{array}{l}\text { Оператор блочного шита } \\
\text { управління }\end{array}$ & 3,1 & 2,34 & - \\
\hline
\end{tabular}

* - за критеріями «Гігієнічної класифікації праці..» (ГН -6.6.1-083-200I); ** - за В.В.Матюхиным /17]. 
вово-емоційного навантаження [28, 29]. За деякими даними патологія у Фінляндії набуває характеру епідемії [30, 33].

Проте виникнення цих станів дослідники пов'язують не лише з умовами праці, а й з багатьма іншими чинниками - соціальні та побутові умови, стосунки в сім'ї, стан навколишнього середовища. Через це нині лише у США «синдром хронічної втоми» включено до переліку професійних захворювань.

Тому, на нашу думку, доцільно приділити увагу виявленню найбільш поширених нозологічних форм захворювань серед працюючих в умовах високої напруженості праці. Останнім часом такий підхід визнається доцільним також деякими іншими науковцями, що працюють у галузі фізіології праці та займаються проблемою професійних ризиків здоров'ю при впливі «фізіологічних» чинників важкості і напруженості праці $[9,16,26]$.

Так, результати комплексних психофізіологічних досліджень в осіб, що виконували роботи з різною категорією напруженості, дозволили встановити наявність кореляційних зв'язків між рівнями середньозмінних показників функціонального стану центральної нервової і серцево-судинної систем та інтегральними показниками напруженості праці. 3а даними наведених авторів, зі зростанням категорії напруженості праці зростає нервово-психічне напруження у чоловіків за рахунок такої характеристики функціонального стану ЦНС, як «ефективність», а у жінок - за характеристикою «стабільність». Поряд 3 цим, спостерігалося зростання напруженості регуляторних механізмів серцево-судинної системи, що проявлялося у зростанні показників гемодинаміки (артеріальний тиск, частота пульсу, зубець Т електрокардіограми). Водночас встановлено зростання активності симпато-адреналової системи рівня концентрації цукру в крові, екскреції катехоламінів (норадреналін, адреналін) із сечею.
Численні докази зв'язку різних рівнів напруженості праці з вираженістю реакцій серцево-судинної системи у різні роки отримали в лабораторії розумової праці Інетитуту медицини праці АМН України В.Г. Крижанівський, О.О.Навакатікян, В.О.Бузунов, Л.О.Томашевська, В.А.Деркач, О.В.Карпенко, Г.І.Қовальова. Зокрема, отримано дані про зміни типу регуляції кровообігу залежно від напруженості виконуваної роботи (рисунок) [10].

Так, при «допустимій» напруженості праці у конструкторів (клас 2 за «Гігієнічною класифікацією праці...») переважав середній, найбільш сприятливий для організму тип саморегуляції кровообігу. При «високій» напруженості праці (інженерипрограмісти, клас $3.1-3.2$ ) було відмічено перехід від «серцевого» типу саморегуляції до найбільш несприятливого «судинного», що, за даними багатьох дослідників, найчастіше призводить до розвитку гіпертонічної хвороби. При «дуже високій напруженості праці» (авіадиспетчери, клас 3.3 ) у стажованих працівників формується переважно «судинний» тип регуляції кровообігу, що не змінюється протягом робочого дня.

Отже, маємо підстави для узагальнення, що зі зростанням напруженості виконуваної роботи суттєво зростає загальне робоче напруження організму людини. За відсутності належного відпочинку, профілактичних заходів, що сприяють процесам відновлення, повторні нервово-психічні навантаження можуть призвести до розвитку стану функціонального перенапруження організму, а відтак до виробничо зумовлених захворювань. У дослідженнях доведено наявність кореляційних зв'язків між величиною інтегрального показника напруженості праці ( $\mathrm{LHn}$ ) і поширеністю захворюваності на гіпертонічну хворобу, ішемічну хворобу серця та невротичні розлади у працюючих в різних професіях напруженої розумової праці [17] (табл. 2).

\begin{tabular}{|c|c|}
\hline 1 & 2 \\
\hline $17 \%$ & $52 \%$ \\
\hline $19 \%$ & $18 \%$ \\
\hline $64 \%$ & $30 \%$ \\
\hline \multicolumn{2}{|c|}{ інженери- } \\
математики \\
\hline
\end{tabular}

\begin{tabular}{|c|c|}
\hline 1 & 2 \\
\hline $12,5 \%$ & $12,5 \%$ \\
\hline $37,5 \%$ & $37,5 \%$ \\
\hline $50 \%$ & $50 \%$ \\
\hline \multicolumn{2}{|c|}{ конструктори } \\
\hline
\end{tabular}

\begin{tabular}{|c|c|}
\hline 1 & 2 \\
\hline $10 \%$ & $8 \%$ \\
\hline $18 \%$ & $15 \%$ \\
\hline $72 \%$ & $77 \%$ \\
\hline \multicolumn{2}{|c|}{ авіадиспетиери } \\
\hline
\end{tabular}

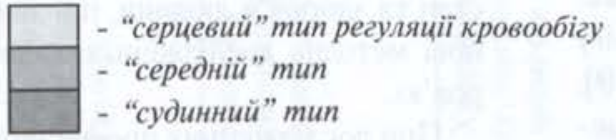

Рисунок. Зміна типів саморегуляиї кровообігу залежно від напруженості праці в динаміці робочого дня у представників різних професій розумової праці (за Г.І.Ковальовою [10])

I - перед роботою; 2 - після роботи. 
Табілщи 2

Результати регресійного аналізу взаємозв'язку між інтегральним показником напруженості праці (Lнп) і виявленням осіб із загальносоматичною патологією (\%) [17]

\begin{tabular}{|c|c|c|c|c|c|}
\hline \multirow{3}{*}{ Нозологія } & \multicolumn{5}{|c|}{ Інтегральний показник напруженості праці (LнII) } \\
\hline & \multicolumn{2}{|c|}{ Без урахування статі } & \multicolumn{3}{|c|}{3 урахуванням статі } \\
\hline & Коефіщієнт корелящії & Рівняння регресії & Стать & Коефіміснт корелямії & Рівняння регресії \\
\hline \multirow[t]{2}{*}{$\begin{array}{l}\text { Гіпертонічна } \\
\text { хвороба }\end{array}$} & \multirow[t]{2}{*}{$\begin{array}{c}0,861 \\
\mathrm{p}<0,01\end{array}$} & \multirow[t]{2}{*}{$\mathrm{y}=5,061+32,9 \mathrm{LHX}$} & Ж & $\begin{array}{c}0,83 \\
\mathrm{p}<0,05\end{array}$ & $y=6,33+32,9 \mathrm{LHX}$ \\
\hline & & & Ч & $\begin{array}{c}0,96 \\
p<0,05\end{array}$ & $\mathrm{y}=6,31,83+45,44 \mathrm{LH} X$ \\
\hline \multirow[t]{2}{*}{$\begin{array}{l}\text { Ішемічна } \\
\text { хвороба серця }\end{array}$} & \multirow[t]{2}{*}{$\begin{array}{c}0,65 \\
p<0,05\end{array}$} & \multirow[t]{2}{*}{$\mathrm{y}=0,67+31,8 \mathrm{LHX}$} & Ж & $\begin{array}{c}0,69 \\
\mathrm{p}<0,05\end{array}$ & $\mathrm{y}=0,94+15,01 \mathrm{LHX}$ \\
\hline & & & ч & $\begin{array}{c}0,98 \\
p<0,05 \\
\end{array}$ & $y=6,39+66,49$ LнX \\
\hline \multirow[t]{2}{*}{$\begin{array}{l}\text { Невротичні } \\
\text { розлади }\end{array}$} & \multirow[t]{2}{*}{$\begin{array}{c}0,67 \\
p<0,05\end{array}$} & \multirow[t]{2}{*}{$\mathrm{y}=19,8+52,8 \mathrm{LHX}$} & Ж & $\begin{array}{c}0,7 \\
\mathrm{p}<0,051\end{array}$ & $y=26,4+58,0 \mathrm{LHX}$ \\
\hline & & & Ч & $\begin{array}{c}0,9 \\
p<0,05\end{array}$ & $\mathrm{y}=6,9+48,9 \mathrm{LHX}$ \\
\hline
\end{tabular}

За даними психофізіологічних та клінічних обстежень авіадиспетчерів основних аеропортів України, проведених Інститутом медицини праці АМНУ, також $€$ всі підстави стверджувати про формування у них стану функціонального перенапруження організму, протягом робочої зміни, причому у $20 \%$ досліджуваних осіб виявлялися ознаки втоми високого ступеня та перевтомлення.

Ці фізіологічні зсуви добре корелюють з відхиленнями у нервово-психічному статусі, захворюваннями на вегето-судинну дистонію, гіпертонічну хворобу.

У таблиці 3 наведено узагальнені дані різних авторів щодо поширеності захворювань нервової та серцево-судинної системи серед працівників різних професій, пов'язаних з високою напруженістю праці.

Дані таблиці свідчать, що у працівників розумової праці, зокрема операторських професій, роботу яких пов'язано зі значними інтелектуальним, сенсорним, емоційним навантаженнями реєструється підвищена захворюваність на невротичні розлади $(4,2-43,9 \%)$, гіпертонічну хворобу $(10,4-36,2 \%)$, ішемічну хворобу серця $(6,2-43,8 \%)$. Етіологічна доля фактора напруженості праці в розвитку захворювань нервової системи та органів кровообігу становить, за даними дисперсійного аналізу [9], $56,8 \%$ та $40,2 \%$ відповідно, а в розвитку ішемічної хвороби серця $-55,2 \%$. Виходячи з того, що у діючому нині переліку професійних захворювань, затвердженому Постановою КМ України від
08.11.2000 р. за № 1661, міститься лише одна нозологічна форма професійного захворювання, пов'язана з напруженістю праці - а саме «неврози». Проведені дослідження дають підстави для рекомендацій щодо розширення цього переліку за рахунок таких нозологій, як «ішемічна хвороба серця» та «гіпертонічна хвороба», а також щодо аналізу поширеності цих захворювань серед експонованих контингентів.

Отже, наведені результати комплексних професіографічних, психофізіологічних та фізіолого-клінічних досліджень у багатьох випадках співпадають, що дає підстави для використання розрахункових показників рівнів вірогідності розвитку тих чи інших виробничо-зумовлених захворювань (зокрема, невротичних розладів, гіпертонічної хвороби, ішемічної хвороби серця) залежно від напруженості виконуваної роботи. Тобто дослідження, що проведено, свідчать про можливість прямих та зворотних лінійних зв'язків між рівнем напруженості праці та розвитком різних ступенів втоми та перевтомлення. А це, в свою чергу, свідчить про реальну можливість встановлення закономірностей «взаємозв'язку» типу «рівень-час» або «рівень-час-ефект» у впливі фактора напруженості праці на функціональний стан та здоров'я людини, що звичайно лежить в основі методик досліджень професійних ризиків здоров’ю.

При дослідженнях професійних ризиків доцільно враховувати категорії доказовості іх наявності на виробництві, що рекомендовано ООН [34]. Адаптовані до діючого в Україні санітарного законодав- 




ले ज्ञ ฐ ฐ ฐ $\approx$ ฐ ธू ญ ミミ 帘 당 ลิ 2 


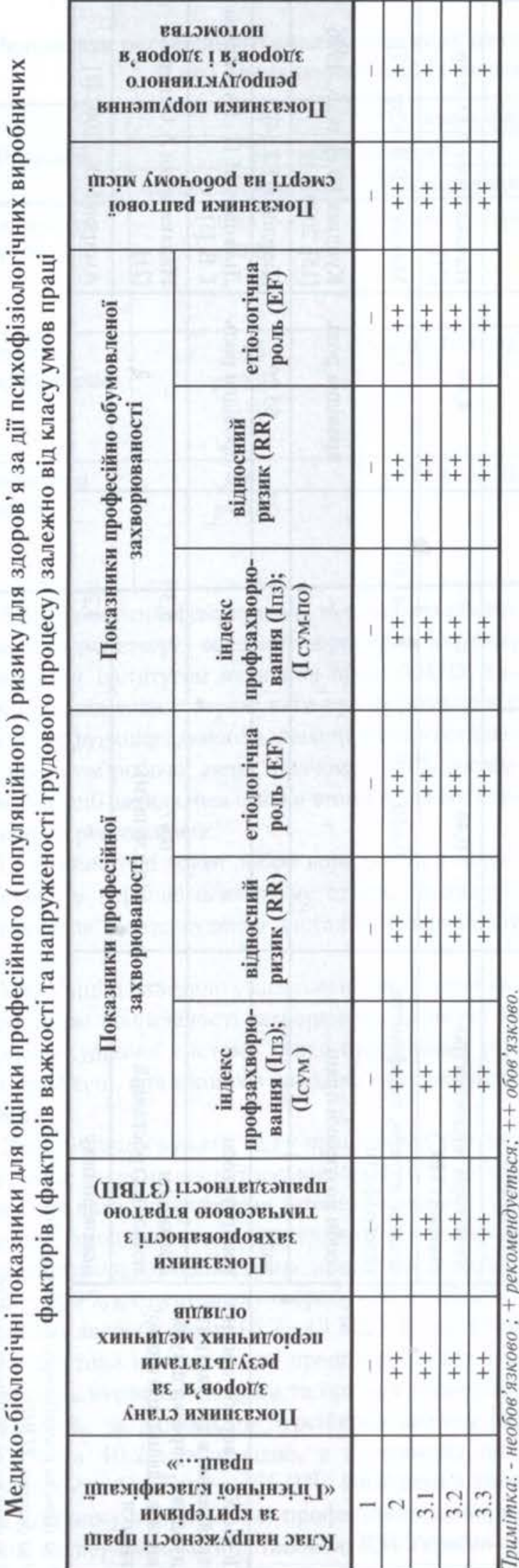

ства та напрацьованих методичних підходів до вивчення професійних ризиків ці категорії доказовості можна навести у такому вигляді:

- Категорія 1А (доведений професійний ризик) базується на результатах гігієнічної оцінки умов праці за критеріями «Гігієнічної класифікації праці...», матеріалах періодичних медичних оглядів, результатах фізіологічних і експериментальних досліджень, а також на даних епідеміологічних досліджень здоров'я;

- Категорія 1Б (передбачуваний/очікуваний/ професійний ризик) - з урахуванням результатів гігієнічної оцінки умов праці за критеріями «Гігієнічної класифікації праці...», доповнених окремими клініко-фізіологічними, лабораторними, експериментальними даними та даними літератури;

- Категорія 2 (підозрюваний професійний ризик) встановлюеться лише на основі результатів гігієнічної оцінки умов праці за критеріями «Гігієнічної класифікації праці...».

Додатковими критеріями для визначення доведеного професійного ризику можуть бути дослідження біологічного віку, порушень репродуктивного здоров'я і здоров'я потомства, смертності і т. ін., як це рекомендують, посилаючися на накопичений досвід досліджень професійних ризиків у Росії, та 3 урахуванням концепцій, прийнятих в різні роки BOO3, МОП, ISO стосовно ціеї проблеми [7].

Результати узагальнення існуючих поглядів та рекомендованих методичних підходів щодо досліджень професійних ризиків здоров'ю, пов'язаних 3 впливом напруженості праці, проведено у таблиці 4 . При цьому перелік рекомендованих медико-біологічних показників для оцінки професійних ризиків, які вже включено до відповідних актів санітарного законодавства, зокрема в Росії (Р 2.2.1766-03 «Руководство по оценке профессионального риска»), доповнено таким важливим, на нашу думку, показником як «раптова смерть на робочому місці».

Індекс профзахворюваності (Із); відносний ризик (RR); етіологічна доля фактора ризику (EF) визначаються за [7].

Отже при розробці методики визначення професійних ризиків здоров'ю, пов'язаних з впливом інформаційних чинників (напруженості праці), доцільно дотримуватися такої класичної схеми:

1. Ідентифікація фактору ризику. У нашому випадку - напруженість праці за показниками та критеріями «Гігієнічної класифікації праці...» (ГН 3.35-3.38;6.6.1-083-2001); 
2. Кількісна оцінка фактора ризику за бальним критерієм, як запропоновано у розділі 3 , або за критерієм Lнп в умовних одиницях;

3. Визначення «підозрюваного» та «очікуваного» ризику за ергономічними критеріями «Гігієнічної класифікації праці...»;

4. Аналіз даних про функціональний стан організму працюючнх в умовах того чи іншого рівня напруженості праці, розвитку у них станів перенапруження та синдрому хронічної втоми (CXB) чи стану «burnout»;

\section{Література}

1. Амиров Н.Х. Труд и здоровье руководителей (гигиеническая, медико-социальная и психофизиологическая оценка условий трудовой деятельности и здоровья руководителей) / Под ред. М.М. Пимадеева.- М.: ГЭОТАР-МЕД. 2002.- 136 с.

2. Березин Ф.Б., Безносюк Е.В., Соколова Е.Д. Психологические механизмы психосоматических заболеваний//Росс, мед. журн.- 1998.- №2.- С. 43-49.

3. Гаркави Л.Х., Квакина Е.Б., Уколова М.А. Адаптационные реакции и.-резистентность организма / Ростов н/Д.: Изд-во Рост. ун-та, 1990.- 224 с.

4. Діордічук Т.І. Особливості умов праці, фактори ризику, шляхи збереження здоров'я водіїв вантажних автомобілів: Автореф, дис....канд. мед. наук.Київ, 2003.- 16 с.

5. Дьякович М.П., Куренкова Г.В. Некоторые аспекты профессиональной деятельности и риска нарушения здоровья конструкторов летательных аппаратов// Гиг. и сан.-2005.-№ 1.- С. 28-29.

6. Зенков Л.Р., Ронкин М.А. Функциональная диагностика нервных болезней.- М.: Медицина, 1991.$640 \mathrm{c}$.

7. Измеров Н.Ф., Денисов Э.И. Профессиональный риск и медицина труда // Профессиональный риск: Справочник.- М.: Издательский Дом "Социздат", 2001.- С. 5-40.

8. Измеров Н.Ф., Капцов В.А., Денисов Э.И., Овакимов В.Г. Проблема оценки профессионального риска в медицине труда // Медицина труда и пром. экол.- 1993.- №3-4.- С. 1-4.

9. Измеров Н.Ф., Матюхин В.В., Тарасова Л.А. Обоснование интегрального показателя для определения категорий напряженности труда// Медицина труда и пром. экол.- 1997.- № 5.- С. 1-7.

10. Ковалева А.И. Факторы формирования напряженности труда и напряжения организма диспетчеров, обслуживающих воздушное движение//Питиена труда: Респ. межвед. сб.- К.: Здоров'я, 2001.Вып.32.- С. 164-175.

11. Коваленко А.Н., Логановский К.Н. Синдром хронической усталости и метаболический синдром Х у пострадавших вследствие чернобыльской катас-
5. Аналіз професійної захворюваності у експонованих контингентів;

6. Аналіз захворюваності з тимчасовою втратою працездатності, інвалідності, смертності, у тому числі раптової смертності на робочому місці та ін.;

7. Аналіз результатів періодичних медичних оглядів;

8. Розрахунки величин відносного ризику, етіологічної долі фактора ризику, його оцінювання та визначення категорії доведеності ризику.

трофы - мембранная патология? //Український медичний часопис.-2001.- №6(26).- С. 70-80.

12.Косицкий Г.И. Нервное напряжение, эмоции, неврозы и сердечно-сосудистая система/ В кн.: Превентивная кардиология. М., 1987.- 147 с.

13.Кундиев Ю.И., Кальниш В.В., Нагорная А.М. Роль стресса в формировании здоровья населения //Журнал АМН Украины.- 2002.- № 2.- С. 335-345.

14. Кундиев Ю.И., Навакатикян А.О. Проблемы психо-эмоционального стресса и пути их решения // Журн. АМН Украины.- 1996.-Т.2.- № 4.- С. 666-673.

15. Кундиев Ю.И., Навакатикян А.О. Проблемы психо-эмоционального стресса и пути их решения // Журн. АМН України.- 1996.- № 4.- С. 666-674.

16. Макаренко Н.А., Павленко М.Е., Белецкий В.С. и др. Заболеваемость с временной утратой трудоспособности рабочих горнорудной промышленности и пути ее снижения // Гигиена труда и профессиональные заболевания.- 1988.- №6.- С. 5-7.

17. Матюхин В.В., Тарасова Л.А., Шардакова Э.Ф. и др. Вероятность нарушения здоровья работающих от воздействия неблагоприятных факторов трудового процесса / / Медицина труда и пром. экол.- 2001.№6.- С. 1-7.

18. Медведев О. С. Эмоциональное напряжение и стресс //Физиология кровообращения.- М.: Наука, 1986.- C. 507-525.

19.Меерсон Ф.З. Адаптация, стресс и профилактика.- М.: Наука, 1981.- 281 с.

20. Навакатикян А.О. Проблема развития предпатологических состояний (перенапряжения и переутомления) под влиянием работы и факторов окружающей среды// Пигиена труда и профзаболевания, 1981, №11,- C.14-18.

21. Навакатикян А.О. Стресс и профилактика его неблагоприятного воздействия.-К.: Знание, 1984.-306 c.

22. Навакатикян А.О., Ковалева А.И. Здоровье и работоспособность при умственном труде - Киев: Здоровья, 1989.- $88 \mathrm{c}$.

23. Навакатикян А.О.. Чукмасова Г.Т., Шаптала А.А. и др. Влияние условий труда на работоспособность и здоровье операторов / Под ред. А.О. Навакатикяна.К.: Здоров'я, 1984.- 144 с. 
24. Пышнов Г.Ю., Апыхтин К.А., Кудиевский Я.В.. Иванов Д.А. Исследование синдрома "выгорания" у лиц диспетчерского состава по управлению воздушным движением // Пигиена труда: Сборник: В 2 тК., 2003.-Вып. 34.- Т. 2.- С. 476-483.

25. Юшкова О.И. Хронический стресс при сменной умственной работе// Мед .труда и пром.әкология.-1999.- №7.- С. 6-12.

26. Юшкова О.И., Матюхин В.В., Шардакова Э.Ф. Психофизиологические аспекты производственного стресса в медицине труда / Медицина труда и промышленная экология.- 2001.- № 8.- С. 1-7.

27. Bultmann U., Kant I., Kasi S.V, et al. Fatigue and psychological distress in the working population psychometrics, prevalence, and correlates/J. Psychosom. Res.-2002.- V. 52.- P. 445-452.

28. Huibers M., Beurskens A., Prins J., et al. Fatigue, burnout, and chronic fatigue syndrome among employees on sick leave: do attributions make the difference?/Occup. Environ. Med.-2003.- V.60.- P. 26-31.
29. Holmes G.P. et al. Chronic fatigue syndrome - a working case definition/Ann. Int. Med.-1998.- V.108.P. 387-389.

30.Matti Tapiainen. Burnout: a national epidemic? Work Health Safety.- 1998.- V.1.- P. 8-18.

31.Ross E. The history and treatment of chronic fatigue syndrome // Nurs. Times.- 1996.- V. 92, №44.P. $34-36$.

32. Swaen G., van Ameisvoort L., BUItmann U., Kant I. Fatigue as a risk factor for being injured in an occupational accident: results from the Maastricht Cohort Study/Occupational and Environmental Medicine.2003.- V.60.- P.88.

33. Teriuchi Shimomitsu. Occupational Stress and health in Japan.//Asian-Pacific Newslett on occup. Health and Safety.- 1999.- V.6.- P. 16-19.

34. UN. Globally harmonized system of classification and labelling of chemicals (GHS).- New York and Geneva:United Nations, 2003 (ISBN 92-1-116840-6).-443 pp. (ООН. Глобально гармонизированная система классификации и маркировки химических веществ).

\title{
HАПРЯ)КЕННОСТЬ ТРУАА КАК ФАКТОР ПРОФЕССИОНААЬНОГО СТРЕССА И РИСКА ЗАОРОВЬЮ
}

\author{
Кунаиев Ю.И.1, Чернюк В.И.', Шевиова В.М.2 \\ 1 Институт меАишины труда АМН Украины, г. Киев \\ 2Украинский НИИ промышленной меАишины, г. Кривой Рог
}

Рассмотрена роль высокого нервно-эмоционального напряжения как фактора риска нарушений здоровья у работников умственного труда. Предложены новые подходы к количественной оценке напряженности труда на основе критериев «Гигиенической классификации труда...». Проанализирована современная литература по вопросам влияния напряженности труда на состояние здоровья и определены основные нозологические формы производственно-обусловленной патологии, к которой может привести влияние этого вредного производственного фактора. С учетом мирового опыта изучения производственных рисков здоровью и современных методических подходов, рекомендована схема организации и проведения исследований по выявлению и оценке рисков, обусловленных влиянием напряженности умственного труда.

Ключевые слова: напряженность труда, профессиональный стресс, здоровье, профессиональный риск, методика определения

\section{WORI STRAIN AS AN OCCUPATIONAL HEALTH STRESS AND RISIK FACTOR}

\section{Kundiev Yu.1.1, Chernyuk V.I.1, Shevtsova V.M.2}

\section{Institute for Occupational Health of AMS of Ukraine, Kiev \\ 2 Ukrainian Scientific Research Institute of Industrial Medicine, Kryvoj Rog}

The article highlights the role of high neuro-emotional strain as a factor of health risk for mental work workers. There were proposed new approaches to quantitative assessment of work strain basing on the criteria of eHygienic Classification of Work». The modern literature data were analyzed concerning the effect of work strain on the state of health and there were determined main nosological types of work-related pathology that might be caused by the effect of that occupational factor. Taking into consideration the world experience in studying occupational health risks and modern methodological approaches a scheme for organization and conducting studies on detection and assessment of risks caused by the effect of mental work strain was recommended.

Key words: work strain, occupational stress, health, occupational risk, method of detection

Надійшла: 13.09.2005

Контактна особа: Чернюк В.І., Інститут медицини праці АМН України, вул. Саксаганського, 75, Київ 01033, Україна 